\title{
STRATEGIES OF RT-PCR-BASED ASSAY DESIGN AND SURVEILLANCE OF SARS-COV-2
}

\author{
Kuznetsova $\mathrm{NA}^{1} \otimes$, Pochtovyy $\mathrm{AA}^{1,2}$, Nikiforova MA ${ }^{1}$, Gushchin VA ${ }^{1,2}$ \\ ${ }^{1}$ Gamaleya Research Institute of Epidemiology and Microbiology, Moscow \\ ${ }^{2}$ Lomonosov Moscow State University, Moscow
}

\begin{abstract}
High population density in the cities with bustling transportation systems and a thriving tourism industry can promote the global spread of a viral infection in a matter of days. The novel SARS-CoV-2 coronavirus has already infected over 2,000,000 people worldwide and caused upwards of 156,000 deaths. One of the factors driving the rapid unfolding of the pandemic is the absence of diagnostic tests for SARS-CoV-2 detection. Molecular techniques allow SARS-CoV-2 RNA to be quickly detected in clinical samples, aiding the differential diagnosis in severely ill patients and facilitating identification of asymptomatic carriers or presymptomatic individuals. Real-time PCR with fluorescent hybridization is the most available, highly sensitive and specific technique for SARS-CoV-2 RNA detection in biological samples. More RT-PCR assay kits are needed for mass screening, which will help to identify infected individuals and contain the current outbreak of COVID-19 in Russia.
\end{abstract}

Keywords: SARS-CoV-2, COVID-19, diagnostics, RT-PCR, assay kits, coronavirus

Author contribution: the autors equally contributed to the manuscript.

Correspondence should be addressed: Nadezhda A. Kuznetsova

Gamalei, 16, str. 1, Moscow, 123098; nadyakuznetsova0@gmail.com

Received: 21.04.2020 Accepted: 28.04.2020 Published online: 30.04.2020

DOI: $10.24075 /$ brsmu.2020.026

\section{СТРАТЕГИИ ДИЗАЙНА РТ-ПЦР-СИСТЕМ И ОРГАНИЗАЦИЯ МОНИТОРИНГА SARS-COV-2}

\author{
Н. А. Кузнецова ${ }^{1}$, А. А. Почтовый ${ }^{1,2}$, М. А. Никифорова ${ }^{1}$, В. А. Гущинн, \\ ${ }^{1}$ Национальный исследовательский центр эпидемиологии и микробиологии имени Н. Ф. Гамалеи, Москва, Россия \\ 2 Московский государственный университет имени М. В. Ломоносова, Москва, Россия
}

\begin{abstract}
Высокая плотность населения в городах с хорошо развитыми транспортными путями сообщения и туризмом может привести к распространению вирусных инфекций по всему миру в считаные дни. Новый коронавирус SARS-CoV-2 стал причиной заболевания COVID-19 уже более 2 000 000 человек и унес жизни более 156000 человек по всему миру. Одной из основных причин такого стремительного развития пандемии послужило отсутствие диагностических тест-систем для выявления SARS-CoV-2. Применение молекулярно-биологических методов дает возможность быстро обнаруживать PHK вируса SARS-CoV-2 в клинических образцах, что позволяет уточнять диагноз у пациентов с тяжелыми формами течения болезни, а также выявлять людей с бессимптомным течением заболевания или находящихся в инкубационном периоде. Наиболее доступным, высокочувствительным и специфичным методом идентификации HK SARS-CoV-2 в биологических образцах является ПЦР с гибридизационно-флуоресцентной детекцией сигнала в режиме реального времени (ПЦР-PB). Текущая вспьшка COVID-19 в России требует наличия как можно большего количества ПЦР-PBтест-систем для проведения масштабных скрининговых исследований с целью выявления инфицированных лиц, своевременное выявление которых является крайне важным условием успешного предотвращения распространения вируса.
\end{abstract}

Ключевые слова: SARS-CoV-2, COVID-19, диагностика, РТ-ПЦР, тест-системы, коронавирус

Вклад авторов: авторы внесли равнозначный вклад в написание статьи.

$\triangle$ Для корреспонденции: Надежда Анатольевна Кузнецова

ул. Гамалеи, д. 16, стр. 1, г. Москва, 123098; nadyakuznetsova0@gmail.com

Статья получена: 21.04.2020 Статья принята к печати: 28.04.2020 Опубликована онлайн: 30.04.2020

DOI: $10.24075 /$ vrgmu.2020.026

The emergence and rapid spread of the novel coronavirus SARS-CoV-2 has sparked the pandemic of COVID-19 [1]. Over 2 billion confirmed cases and more than 150, 000 deaths were reported within less than 3 months after the infection found its way out of China [2]. In the absence of specific treatments and vaccines, quarantine and lockdown are seen as the only available containment measure [3]. Since the virus is capable of presymptomatic transmission, molecular diagnostic techniques based on the amplification of nucleic acids have become the primary tool for monitoring its spread [4]. China, Singapore, South Korea, and Germany succeeded in implementing the broad testing strategy using reverse-transcription polymerase chain reaction (RT-PCR) kits and thus were able to timely identify individuals infected with SARS-CoV-2; these countries seem to have gained control of the epidemic and saved medical resources for treating critically ill patients. By contrast, Italy, Sweden and USA, who were late to adopt the broad testing strategy or initially denied its efficacy, are now facing a truly grave situation.
Molecular methods based on the amplification of nucleic acids boast high sensitivity and high specificity; they can detect viral RNA in both severely ill patients and asymptomatic individuals and thus significantly contribute to stemming the spread of the virus $[5,6]$. Immediately after the first complete SARS-CoV-2 genome sequences were obtained, Chinese researchers and $\mathrm{WHO}$ released primer and probe sequences for PCR-based virus detection; in the months that followed, thousands of SARS-CoV-2 whole genomes were sequenced and new RT-PCR assays were developed. In this article, we talk about the main approaches to designing PCR assays and some of their specific characteristics.

In diagnostic tests, proper sample collection techniques and adequate, informative samples are essential to valid and reliable results. Knowledge of viral tropism is critical to choosing the type of the specimen to be collected. The efficacy of RTPCR for SARS-CoV-2 detection depends on the specimen source and the applied sampling technique. It is reported that bronchoalveolar lavage fluids have the highest diagnostic value 
in terms of SARS-CoV-2 detection, followed by sputum, nasal swabs, fibrobronchoscope brush biopsy, pharyngeal swabs, feces, and blood (1\%) [7]. Still, nasal and oropharyngeal swabs remain the most available and informative specimen type used in screening tests for SARS-CoV-2 [8, 9]. When properly performed, swabbing allows obtaining good quality samples and is safe for the medical staff [10].

Real-time PCR with fluorescent hybridization probes (real-time PCR) is the primary molecular genetic technique for SARS-CoV-2 detection [6, 11, 12]. It is widely available, highly sensitive and specific. PCR assay kits are instrumental in implementing mass screening aimed at detecting infected individuals and quantifying viral loads in each patient.

\section{Approaches RT-PCR assay design}

So far, the oligonucleotides and real-time RT-PCR kits for SARS-CoV-2 detection have been described in a few dozens of publications by international authors. In those studies, several different approaches can be identified to designing real-time RT-PCR assays for SARS-CoV-2 detection. Singleplex PCR assays, in which oligonucleotides are selected to target only one specific gene, are the simplest and the most available. Multiplex assays are more advanced and allow targeting a number of different genes simultaneously. Primers and probes for multiplex assays can have different specificity or enable discrimination between SARS-CoV-2 and the related coronaviruses or other respiratory infections. For SARS-CoV-2 detection, primers and probes are usually selected to target the nucleocapsid genes N1 and N2, the RNA-dependent RNA polymerase gene $(R d R P)$ and the $\mathrm{E}$ protein gene of the viral envelope. For example, CDC (Centers for Disease Control and Prevention) recommends that identification of COVID-19 patients should start with a screening test for the E protein gene, whose nucleotide sequence does not differ from that of SARS, and then proceed to differentiating SARS from SARS-CoV-2 using oligonucleotides for the RdRP target [13]. According to the WHO protocol, the collected samples should be screened for $N$ and Orf1b. However, the proposed oligonucleotides do not help in discriminating between SARS-CoV-2 and SARS; therefore, sequencing is advised to finalize the identification procedure [14]. Table 1 features publicly accessible primer and probe sequences for SARS-CoV-2 detection recommended by $\mathrm{WHO}$ and CDC.

\section{Characteristics of existing RT-PCR assays for SARS-CoV-2 detection}

Due to high demand, over 10 different commercial kits for SARS-CoV-2 detection have been launched on the Russian market; some of them have already received a medical device registration certificate (Table 2). Singleplex kits have higher sensitivity (up to $500 \mathrm{GE} / \mathrm{ml}$ ) than their multiplex counterparts $(1,000$ to $10,000 \mathrm{GE} / \mathrm{ml})$, whereas multiplex kits targeting several SARS-CoV-2 genes are more specific and help to avoid false-negative results associated with the variability of the virus resulting from mutations at the oligonucleotide binding site. Of note, results generated by multiplex kits are sometimes difficult to interpret due to the insufficient optimization of the oligonucleotide sequence. Nevertheless, all Russian manufacturers claim the sensitivity of their kits to be 1,000 GE/ml. Importantly, an internal control should be included in the kit, regardless of the number of specific targets. The internal control can be endogenous (human DNA) or exogenous (e.g., an RNA phage). It is used to control all stages of the protocol, from nuclear acid extraction to amplification.

Although the internal control is necessary, not every assay has it. For example, it is not found in the kits based on isothermal amplification, including loop-mediated isothermal amplification (LAMP). Such assays are advantageously fast (they take no longer than $40 \mathrm{~min}$ ), do not require sophisticated instrumentation and can be used as point-of-care tests outside the lab, as no thermocycler is needed. LAMP-based assays boast a sensitivity of up to 1-3 RNA copies per reaction [15]. However, the actual sensitivity of currently available commercial LAMP assays is lower than claimed (Table 2).

\section{Whole-genome sequencing}

Among all techniques for molecular genetic analysis, sequencing still has the highest informative value. In the current pandemic caused by SARS-CoV-2, the number of complete

Table 1. Oligonucleotides recommended for COVID-19 diagnostics by WHO and CDC

\begin{tabular}{|c|c|c|c|}
\hline & Target & Oligonucleotides & Detection \\
\hline \multirow{2}{*}{ WHO } & ORF1b-nsp14 & $\begin{array}{l}\text { HKU-ORF1b-nsp14F TGGGGYTTTACRGGTAACCT } \\
\text { HKU- ORF1b-nsp14R AACRCGCTTAACAAAGCACTC } \\
\text { HKU-ORF1b-nsp141P FAM-TAGTTGTGATGCWATCATGACTAG-BHQ1 }\end{array}$ & $\begin{array}{l}\text { SARS coronavirus } \\
\text { BetaCoV/bat } \\
\text { Bat SARS-like coronavirus } \\
\text { SARS-CoV-2 }\end{array}$ \\
\hline & $\mathrm{N}$ gene & $\begin{array}{l}\text { HKU-NF TAATCAGACAAGGAACTGATTA } \\
\text { HKU-NR CGAAGGTGTGACTTCCATG } \\
\text { HKU-NP FAM-GCAAATTGTGCAATTTGCGG-BHQ1 }\end{array}$ & $\begin{array}{l}\text { SARS coronavirus } \\
\text { BetaCoV/bat } \\
\text { Bat SARS-like coronavirus } \\
\text { SARS-CoV-2 }\end{array}$ \\
\hline \multirow{3}{*}{ CDC } & envelope protein & $\begin{array}{l}\text { E_Sarbeco_F ACAGGTACGTTAATAGTTAATAGCGT } \\
\text { E_Sarbeco_R ATATTGCAGCAGTACGCACACA } \\
\text { E_Sarbeco_P1 FAM-ACACTAGCCATCCTTACTGCGCTTCG-BHQ1 }\end{array}$ & $\begin{array}{l}\text { SARS coronavirus } \\
\text { BetaCoV/bat } \\
\text { Bat SARS-like coronavirus } \\
\text { SARS-CoV-2 }\end{array}$ \\
\hline & $\mathrm{N}$ gene & $\begin{array}{l}\text { N_Sarbeco_F CACATTGGCACCCGCAATC } \\
\text { N_Sarbeco_R GAGGAACGAGAAGAGGCTTG } \\
\text { N_Sarbeco_P FAM-ACTTCCTCAAGGAACAACATTGCCA-BHQ1 }\end{array}$ & $\begin{array}{l}\text { SARS coronavirus } \\
\text { BetaCoV/bat } \\
\text { Bat SARS-like coronavirus } \\
\text { SARS-CoV-2 }\end{array}$ \\
\hline & RdRP gene & $\begin{array}{l}\text { RdRp_SARSr-F GTGARATGGTCATGTGTGGCGG } \\
\text { RdRp_SARSr-R CARATGTTAAASACACTATTAGCATA } \\
\text { RdRP_SARSr-P1 FAM-CCAGGTGGWACRTCATCMGGTGATGC-BHQ1 } \\
\text { RdRp_SARSr-P2 FAM-CAGGTGGAACCTCATCAGGAGATGC-BHQ1 }\end{array}$ & $\begin{array}{l}\text { SARS coronavirus } \\
\text { BetaCoV/bat } \\
\text { Bat SARS-like coronavirus } \\
\text { SARS-CoV-2 } \\
\text { SARS-CoV-2 } \\
\text { BetaCoV/bat }\end{array}$ \\
\hline
\end{tabular}


Table 2. Kits for SARS-CoV-2 RNA detection

\begin{tabular}{|c|c|c|c|c|}
\hline $\begin{array}{c}\text { Certificate ID and } \\
\text { registration date } \\
\text { (Federal Service } \\
\text { for Surveillance in } \\
\text { Healthcare) }\end{array}$ & Name & Manufacturer & $\begin{array}{l}\text { Claimed } \\
\text { sensitivity } \\
(\mathrm{GE} / \mathrm{ml})\end{array}$ & $\begin{array}{l}\text { Amplification } \\
\text { time }\end{array}$ \\
\hline $\begin{array}{l}2020 / 10088 \\
\text { dated } 17.04 .2020\end{array}$ & $\begin{array}{l}\text { Real-time isothermal amplification kit for SARS-CoV-2 RNA } \\
\text { detection in biological samples }\end{array}$ & Evotech Mirai Genomics LLC & 10000 & $25 \min$ \\
\hline $\begin{array}{l}2020 / 10064 \\
\text { dated } 16.04 .2020\end{array}$ & $\begin{array}{l}\text { SBT-DX-SARS-CoV-2 Real-time PCR kit for SARS-CoV-2 RNA detection } \\
\text { in biological samples (fluorescent hybridization) }\end{array}$ & SystemaBioTech LLC & 1000 & $1 \mathrm{~h} 40 \mathrm{~min}$ \\
\hline $\begin{array}{l}2020 / 9957 \\
\text { dated } 02.04 .2020\end{array}$ & $\begin{array}{l}\text { Isotherm SARS-CoV-2 RNA-screen Real-time loop-mediated } \\
\text { isothermal amplification kit for SARS-CoV-2 RNA detection in } \\
\text { biological samples }\end{array}$ & Generium JSC & 1000 & $25 \mathrm{~min}$ \\
\hline $\begin{array}{l}2020 / 9948 \\
\text { dated } 01.04 .2020\end{array}$ & $\begin{array}{l}\text { SARS-CoV-2/SARS-CoV Real-time RT-PCR kit for SARS-CoV-2 } \\
\text { and SARS-CoV RNA detection }\end{array}$ & DNA-Technology TS LLC & 1000 & $50 \mathrm{~min}$ \\
\hline $\begin{array}{l}2020 / 10032 \\
\text { dated } 14.04 .2020\end{array}$ & $\begin{array}{l}\text { Real-time PCR kit for SARS-CoV-2 RNA detection in biological } \\
\text { samples (fluorescent hybridization) }\end{array}$ & MediapalTech LLC & 1000 & $1 \mathrm{~h} 20 \mathrm{~min}$ \\
\hline $\begin{array}{l}2020 / 9904 \\
\text { dated } 27.03 .2020\end{array}$ & Polyvir SARS-CoV-2 RT-PCR kit for SARS-CoV-2 RNA detection & Litech LLC & 1000 & $1 \mathrm{~h} 30 \mathrm{~min}$ \\
\hline $\begin{array}{l}2020 / 9765 \\
\text { dated } 27.03 .2020\end{array}$ & AmpliTest SARS-CoV-2 PCR kit for SARS-Cov-2 RNA detection & $\begin{array}{l}\text { Center for Strategic Planning, } \\
\text { Ministry of Healthcare of the } \\
\text { Russian Federation }\end{array}$ & 1000 & $1 \mathrm{~h} 20 \mathrm{~min}$ \\
\hline $\begin{array}{l}\text { 2020/9896 } \\
\text { dated } 27.03 .2020\end{array}$ & $\begin{array}{l}\text { Real-Best RNA SARS-CoV-2 RT-PCR kit for SARS-CoV-2 } \\
\text { RNA detection }\end{array}$ & Vector-Best JSC & 1000 & $1 \mathrm{~h} 20 \mathrm{~min}$ \\
\hline $\begin{array}{l}419562014 / 1987 \\
\text { dated } 25.03 .2020\end{array}$ & $\begin{array}{l}\text { AmpliSense }{ }^{\circledast} \text { CoVs-Bat-FL } \\
\text { PCR kit for MERS-CoV and SARS-CoV/CoV-2 RNA detection } \\
\text { in biological samples (fluorescent hybridization); technical } \\
\text { specifications 9398-224-01897593-2013 }\end{array}$ & $\begin{array}{l}\text { Central Research Institute } \\
\text { of Epidemiology, Federal } \\
\text { Service for Surveillance } \\
\text { in Healthcare }\end{array}$ & 1000 & $1 \mathrm{~h} 20 \mathrm{~min}$ \\
\hline $\begin{array}{l}2020 / 9845 \\
\text { dated } 20.03 .2020\end{array}$ & $\begin{array}{l}\text { Real-time isothermal amplification kit for SARS-CoV-2 } \\
\text { RNA detection in biological samples }\end{array}$ & SmartLifeCare LLC & 10000 & $25 \mathrm{~min}$ \\
\hline $\begin{array}{l}413902020 / 9700 \\
\text { dated } 14.02 .2020\end{array}$ & $\begin{array}{l}\text { Vector-OneStepPCR-Cov-RG } \\
\text { Real-time PCR kit for SARS/COVID-19 RNA detection } \\
\text { (fluorescent hybridization) }\end{array}$ & $\begin{array}{l}\text { Vector, State Research } \\
\text { Center of Virology and } \\
\text { Biotechnology, Federal } \\
\text { Service for Surveillance } \\
\text { in Healthcare }\end{array}$ & $\mathrm{n} / \mathrm{a}$ & $\mathrm{n} / \mathrm{a}$ \\
\hline $\begin{array}{l}412402020 / 9677 \\
\text { dated } 11.02 .2020\end{array}$ & $\begin{array}{l}\text { Vector-real-time PCR-2019-nCoV-RG Real-time PCR kit } \\
\text { for 2019-nCoV RNA detection (fluorescent hybridization) }\end{array}$ & $\begin{array}{c}\text { Vector, State Research } \\
\text { Center of Virology and } \\
\text { Biotechnology, Federal } \\
\text { Service for Surveillance } \\
\text { in Healthcare }\end{array}$ & $\mathrm{n} / \mathrm{a}$ & $\mathrm{n} / \mathrm{a}$ \\
\hline
\end{tabular}

genomic sequences of the virus obtained within very short time is record-breaking. Whole-genome sequencing has never been so close to adoption in the clinical setting as it is now. There are a few approaches to whole-genome sequencing of SARS-CoV-2. The classic approach consists in the extraction of nucleic acids from nasopharyngeal and/or oropharyngeal swabs, subsequent depletion of the host's ribosomal RNA for library preparation and sequencing itself carried out according to the protocols supplied by the manufacturer. However, this approach requires a fair amount of viral RNA and good read depth. With low viral loads, the virus can be replicated using cell cultures. For that, serial passages are performed in Vero $\mathrm{V}$, Vero E6, LLC-MK2, and some other cell lines. This approach has been successfully used in some laboratories, including the Reference center for coronavirus infection (GISAID ID: EPI ISL_421275).

Whole-genome amplification is an alternative to cell cultures. So far, a few panels have been designed for sequencing the entire genome of SARS-CoV-2. Among them is the Ion AmpliSeq SARS-CoV-2 Research Panel (Thermo Fisher Scientific; USA). It consists of two primer pools for the amplification of 125-275 bp-long fragments [16].

Another panel was developed by Paragon Genomics Inc (USA). It is a multiplex PCR research panel with two primer pools and an average amplicon size of $99 \mathrm{bp}$ [17]. The panel can potentially detect 1.15 viral copies at $95 \%$ probability.
Using two overlapping pools of primers will ensure full coverage of the entire viral genome, with a calculated detection limit of 0.29 copies at $95 \%$ probability. So far, there is no data on the actual SARS-CoV-2 detection limit for the AmpliSeq SARSCoV-2 Research Panel.

A new protocol for sample preparation and bioinformatic analysis was proposed by the ARTIC network [18]. It was developed for Oxford Nanopore sequencing platform and generates results within $8 \mathrm{~h}$.

\section{CONCLUSIONS}

Methods based on the molecular genetic analysis of nucleic acids are instrumental in the surveillance and monitoring of SARS-CoV-2 spread and help to contain the COVID-19 pandemic. Their primary advantage over thermometry or evaluation of symptoms is the ability to detect asymptomatic carriers or infected presymptomatic individuals. In spite of a plethora of designs, classic RT-PCR is still the preferred detection technique. Refinement of isothermal amplification tools will make molecular analytical techniques more accessible in the future and improve their efficacy in monitoring and controlling biological threats. Sequencing allows accumulating more data about changes occurring in the viral genome and using it for RT-PCR primer optimization, vaccine development, study of the evolution of the virus, and 
reconstruction of epidemiological processes that drive the epidemic. Sequencing platforms make it possible to analyze collected samples in the clinical setting, outside the lab, thereby reducing the turnaround time.

\section{References}

1. Li Q, et al. Early transmission dynamics in Wuhan, China, of novel coronavirus-infected pneumonia. N Engl J Med. 2020; 382: 1199-207.

2. Available from: https://gisanddata.maps.arcgis.com/apps/ opsdashboard/index.html\#/bda7594740fd40299423467b48e9ecf6.

3. Kissler SM, Tedijanto C, Goldstein E, Grad YH, Lipsitch M. Projecting the transmission dynamics of SARS-CoV-2 through the postpandemic period. Science. 2020; eabb5793.

4. He X, Lau EHY, Wu P, et al. Temporal dynamics in viral shedding and transmissibility of COVID-19. Nat Med. 2020. Available from: https://doi.org/10.1038/s41591-020-0869-5.

5. Cheng MP, Papenburg J, Desjardins M, Kanjilal S, Quach C, Libman M, et al. Diagnostic Testing for Severe Acute Respiratory Syndrome-Related Coronavirus-2: A Narrative Review. Ann Intern Med. 2020; Apr 13: [Epub ahead of print]. DOI: 10.7326/M20-1301.

6. Shen M, Zhou Y, Ye J, Abdullah Al-Maskri AA, Kang Y, Zeng S, et al. Recent advances and perspectives of nucleic acid detection for coronavirus. J Pharm Anal. 2020 Mar 1. Available from: https:// www.journals.elsevier.com/journal-of-pharmaceutical-analysis.

7. Wang $W, X u Y$, Gao R, Lu R, Han K, Wu G, et al. Detection of SARS-CoV-2 in Different Types of Clinical Specimens. JAMA. 2020 Mar 11

8. Pan Y, Zhang D, Yang P, Poon LLM, Wang Q.Viral load of SARSCoV-2 in clinical samples. Lancet Infect Dis. 2020 Apr; 20 (4): 411-2.

9. Zou L, Ruan F, Huang M, Liang L, Huang H, Hong Z, et al. SARSCoV-2 Viral Load in Upper Respiratory Specimens of Infected Patients. N Engl J Med. 2020 Mar 19; 382 (12): 1177-9.

10. Marty FM, Chen K, Verrill KA. How to Obtain a Nasopharyngeal
Swab Specimen April 17, 2020. DOI: 10.1056/NEJMvcm2010260.

11. Cheng MP, Papenburg J, Desjardins M, Kanjilal S, Quach C, Libman M, et al. Diagnostic Testing for Severe Acute Respiratory Syndrome-Related Coronavirus-2: A Narrative Review. Ann Intern Med. 2020 Apr; 13

12. Pang J, Wang MX, Ang IYH, Tan SHX, Lewis RF, et al. Potential Rapid Diagnostics, Vaccine and Therapeutics for 2019 Novel Coronavirus (2019-nCoV): A Systematic Review. J Clin Med. 2020 Feb 26; 9 (3): pii E623.

13. Corman VM, Landt O, Kaiser M, Molenkamp R, Meijer A, Chu DK, et al. Detection of 2019 novel coronavirus (2019-nCoV) by realtime RT-PCR. Euro Surveill. 2020 Jan; 25 (3).

14. Available from: https://www.who.int/docs/default-source/ coronaviruse/peiris-protocol-16-1-20.pdf?sfyrsn=af1aac73_4.

15. R Lu, XWu, Z Wan, Y Li, L Zuo, J Qin, et al. Development of a Novel Reverse Transcription Loop-Mediated Isothermal Amplification Method for Rapid Detection of SARS-CoV-2. Virologica Sinica. 2020; c .1.

16. Available from: https://www.thermofisher.com/ru/ru/home/lifescience/sequencing/dna-sequencing/microbial-sequencing/ microbial-identification-ion-torrent-next-generation-sequencing/ viral-typing/coronavirus-research.html.

17. Li C, et al. High sensitivity detection of coronavirus SARS-CoV-2 using multiplex PCR and a multiplex-PCR-based metagenomic method. bioRxiv. 2020

18. Available from: https://nanoporetech.com/about-us/news/articnetwork-provides-protocol-rapid-accurate-sequencing-novelcoronavirus-ncov-2019.

\section{Литература}

1. Li Q, et al. Early transmission dynamics in Wuhan, China, of novel coronavirus-infected pneumonia. N Engl J Med. 2020; 382: 1199-207.

2. Available from: https://gisanddata.maps.arcgis.com/apps/ opsdashboard/index.htm/\#/bda7594740fd40299423467b48e9ecf6.

3. Kissler SM, Tedijanto C, Goldstein E, Grad YH, Lipsitch M. Projecting the transmission dynamics of SARS-CoV-2 through the postpandemic period. Science. 2020; eabb5793.

4. He X, Lau EHY, Wu P, et al. Temporal dynamics in viral shedding and transmissibility of COVID-19. Nat Med. 2020. Available from: https://doi.org/10.1038/s41591-020-0869-5.

5. Cheng MP, Papenburg J, Desjardins M, Kanjilal S, Quach C, Libman M, et al. Diagnostic Testing for Severe Acute Respiratory Syndrome-Related Coronavirus-2: A Narrative Review. Ann Intern Med. 2020; Apr 13: [Epub ahead of print]. DOI: 10.7326/M2O-1301.

6. Shen M, Zhou Y, Ye J, Abdullah Al-Maskri AA, Kang Y, Zeng S, et al. Recent advances and perspectives of nucleic acid detection for coronavirus. J Pharm Anal. 2020 Mar 1. Available from: https:// www.journals.elsevier.com/journal-of-pharmaceutical-analysis.

7. Wang W, Xu Y, Gao R, Lu R, Han K, Wu G, et al. Detection of SARS-CoV-2 in Different Types of Clinical Specimens. JAMA. 2020 Mar 11

8. Pan Y, Zhang D, Yang P, Poon LLM, Wang Q.Viral load of SARSCoV-2 in clinical samples. Lancet Infect Dis. 2020 Apr; 20 (4): 411-2.

9. Zou L, Ruan F, Huang M, Liang L, Huang H, Hong Z, et al. SARSCoV-2 Viral Load in Upper Respiratory Specimens of Infected Patients. N Engl J Med. 2020 Mar 19; 382 (12): 1177-9.

10. Marty FM, Chen K, Verrill KA. How to Obtain a Nasopharyngeal
Swab Specimen April 17, 2020. DOI: 10.1056/NEJMvcm2010260.

11. Cheng MP, Papenburg J, Desjardins M, Kanjilal S, Quach C, Libman M, et al. Diagnostic Testing for Severe Acute Respiratory Syndrome-Related Coronavirus-2: A Narrative Review. Ann Intern Med. 2020 Apr; 13.

12. Pang J, Wang MX, Ang IYH, Tan SHX, Lewis RF, et al. Potential Rapid Diagnostics, Vaccine and Therapeutics for 2019 Novel Coronavirus (2019-nCoV): A Systematic Review. J Clin Med. 2020 Feb 26; 9 (3): pii E623.

13. Corman VM, Landt O, Kaiser M, Molenkamp R, Meijer A, Chu DK, et al. Detection of 2019 novel coronavirus (2019-nCoV) by realtime RT-PCR. Euro Surveill. 2020 Jan; 25 (3).

14. Available from: https://www.who.int/docs/default-source/ coronaviruse/peiris-protocol-16-1-20.pdf?sfvrsn=af1aac73_4

15. R Lu, X Wu, Z Wan, Y Li, L Zuo, J Qin, et al. Development of a Novel Reverse Transcription Loop-Mediated Isothermal Amplification Method for Rapid Detection of SARS-CoV-2. Virologica Sinica. 2020; c. 1.

16. Available from: https://www.thermofisher.com/ru/ru/home/lifescience/sequencing/dna-sequencing/microbial-sequencing/ microbial-identification-ion-torrent-next-generation-sequencing/ viral-typing/coronavirus-research.html.

17. Li C, et al. High sensitivity detection of coronavirus SARS-CoV-2 using multiplex PCR and a multiplex-PCR-based metagenomic method. bioRxiv. 2020.

18. Available from: https://nanoporetech.com/about-us/news/articnetwork-provides-protocol-rapid-accurate-sequencing-novelcoronavirus-ncov-2019. 